\title{
PENINGKATAN KEAKTIPAN DAN HASIL BELAJAR BAHASA INGGRIS KOMPETENSI MENULIS DALAM TEKS PROSEDUR MELALUI MODEL PEMBELAJARAN MAKE A MATCH SISWA KELAS IX MTS NEGERI 5 KUNINGAN TAHUN PELAJARAN 2019/2020
}

\author{
Herdi Ramdhani Sobandi \\ MTsN 5 Kuningan \\ Jl. Tsanawiyah No. 25 Darma \\ Kabupaten Kuningan, Jawa Barat, Indonesia \\ herdiramdhani9@gmail.com
}

\begin{abstract}
ABSTRAK: Penelitian ini bertujuan untuk mengetahui peningkatan hasil belajar serta keaktifan siswa dalam pembelajaran mata pelajaran Bahasa Inggris kompetensi menulis teks prosedur dengan menerapkan model pembelajaran Make a Match. Metodologi yang digunakan adalah Penelitian Tindakan Kelas model Kemis dan Mc Tagart yang dilaksanakan dalam dua siklus yang setiap siklusnya terdapat kegiatan perencanaan, tindakan, pengamatan, dan refleksi. Secara keseluruhan (dua siklus) hasil penelitian ini adalah bahwa penerapan model pembelajaran Make a Match berhasil meningkatkan ketuntasan dari 2 siswa $(5,71 \%)$ menjadi 29 siswa $(82,85 \%)$ atau naik 27 siswa $(77,14 \%)$. Sementara keaktifan siswa mengalami kenaikan dari rata-rata 25 siswa pada siklus 1 (71,42\%), menjadi rata-rata 32 siswa pada siklus $2(94,28 \%)$.

KATA KUNCI: Make a Match; Prosedur Text; keaktifan belajar; keterampilan menulis.
\end{abstract}

\section{IMPROVEMENT OF ENGLISH LEARNING ACTIVITY AND OUTCOMES WRITING COMPETENCY IN PROSEDUR TEXT THROUGH MAKE A MATCH LEARNING MODEL FOR STUDENTS CLASS IX STATE MTs 5 BRASS IN 2019/2020}

\begin{abstract}
ABSTRAK: This study aims to determine the increase in learning outcomes and student activeness in English learning competency in writing prosedur text by applying the Make a Match learning model. The methodology used was the Classroom Action Research model of Kemis and Mc Tagart which was carried out in two cycles, each of which contained planning, action, observation, and reflection activities. Overall (two cycles) the results of this study were that the application of the Make a Match learning model succeeded in increasing the completeness of 2 students $(5.71 \%)$ to 29 students $(82.85 \%)$ or an increase of 27 students (77.14\%). While student activeness has increased from an average of 25 students in cycle 1 $(71.42 \%)$, to an average of 32 students in cycle $2(94.28 \%)$.

KEYWORDS: Make a Match; Prosedur Text; active learning; writing skills.

\begin{tabular}{lccc}
\hline Diterima: & Direvisi: & Distujui: & Dipublikasi: \\
24-09-2020 & 30-09-2020 & $30-09-2020$ & $28-10-2020$ \\
Pustaka & Sobandi, H. R. (2020). Peningkatan Keaktipan Dan Hasil Belajar Bahasa Inggris Kompetensi \\
& Menulis Dalam Teks Prosedur Melalui Model Pembelajaran Make A Match Siswa Kelas Ix \\
& Mts Negeri 5 Kuningan Tahun Pelajaran 2019/2020. Fon : Jurnal Pendidikan Bahasa dan \\
DOI & Sastra Indonesia, 16(2), 60-77. & \\
\hline
\end{tabular}
\end{abstract}

\section{PENDAHULUAN}

Bahasa Inggris adalah bahasa internasional yang digunakan dalam segala bidang di seluruh dunia. Sebagian besar pusat bisnis dan perkantoran yang mempunyai level internasional menggunakan Bahasa Inggris sebagai bahasa lisan dan tulis. Apalagi di era komunikasi dan globalisasi dimana dibuka pasar bebas, kemampuan Bahasa Inggris (language skill) merupakan sebuah syarat mutlak yang harus dimiliki oleh setiap orang. Apabila seseorang tidak mempunyai kemampuan berbahasa Inggris dengan baik maka dia akan tertinggal oleh jaman. 
Pembelajaran Bahasa Inggris (Language Learning) di jenjang SMP/MTs merupakan materi pokok sebagai bagian dari fungsi pengembangan diri siswa dalam bidang Ilmu Pengetahuan, teknologi dan seni yang diharapkan setelah menamatkan studi, mereka mampu tumbuh dan berkembang menjadi individu yang cerdas, terampil dan berkepribadian sebagai bekal hidup di masa mendatang.

Penguasan materi pelajaran Bahasa Inggris di jenjang SMP/MTs meliputi empat keterampilan berbahasa, yaitu: menyimak, berbicara, membaca dan menulis. Semua itu didukung oleh unsurunsur bahasa lainnya, yaitu: kosa kata, tata bahasa dan pronunciation sesuai dengan tema sebagai alat pencapai tujuan. Dari ke empat keterampilan berbahasa di atas, writing (menulis) merupakan salah satu kemampuan berbahasa yang dirasa sering menjadi masalah bagi siswa dalam proses pembelajaran Bahasa Inggris. Hal tersebut sangat menarik untuk diteliti mengingat kemampuan menulis (writing ability) sangatlah dipengaruhi oleh penguasaan kosa kata, struktur bahasa dan kemampuan siswa dalam merangkai kata menjadi sebuah teks yang berterima. Perbedaan secara grammatical antara bahasa Inggris sebagai bahasa asing dan bahasa Indonesia sebagai bahasa utama merupakan masalah yang sering timbul pada saat belajar menulis. Kemampuan mengungkapkan makna dalam langkah retorika dalam essai pendek sederhana dengan menggunakan ragam bahasa tulis secara akurat, lancar dan berterima untuk berinteraksi dalam konteks kehidupan sehari-hari dalam teks berbentuk prosedur dan report adalah salah satu Kompetensi Dasar (KD) yang harus dikuasai oleh siswa Kelas IX Sekolah Menengah Pertama (SMP).

Pembelajaran mengungkapkan makna dalam langkah retorika dalam essai pendek sederhana dengan menggunakan ragam bahasa tulis secara akurat, lancar dan berterima untuk berinteraksi dalam konteks kehidupan sehari-hari dalam teks berbentuk prosedur telah penulis lakukan secara klasikal. Dalam pembelajaran tersebut penulis menjelaskan materi pokok yang terdapat dalam indikator menyusun kalimat acak menjadi teks yang padu berbentuk prosedur.

Dalam penelitian ini penulis memilih metode Make A Match dalam pembelajaran dimana hal tersebut dinilai cocok untuk penelitian ini. Jika mengkaji penelitian lain Penulis melihat efektifitas metode ini dalam mata pelajaran lain seperti Febriana (2011) untuk mata pelajaran IPS. Masa, Murda, \& Mahadewi (2017) untuk siswa kelas lima SD. Harefa (2020) untuk mata pelajaran Geografi. Maka melihat tiga penelitian tersebut yang berhasil meningkatkan aktivitas belajar siswa menjadi lebih baik peneliti melihat juga peneliti lain yang meneliti proses pembelajaran Bahasa inggris.

Peneliti menemukan penelitian Nafis (2015) Dalam peningkatan Bahasa Inggris siswa kelas III MI mengalami peningkatan, Untuk Jenjang SMP peneliti melihat hasil yang dikemukakan oleh Suprapta (2020) Mampu meningkatkan hasil belajar bahasa inggri siswa kelas 7 SMP dengan hasil yang diperoleh pada awalnya mencapai nilai rata-rata 66,40 , pada siklus I mencapai nilai rata-rata 71,87 dan pada siklus II mencapai nilai rata-rata 81,71 .

Sebagai data awal penelitian, penulis mencatat bahwa di kelas IX MTs Negeri 5 Kuningan, tempat penulis mengajar, hasil pre test untuk kompetensi menulis teks prosedur sederhana masih jauh dari harapan. Dari 35 siswa baru dua siswa $(6,67 \%)$ yang mencapai nilai $\geq 70$, empat belas siswa (40\%) mencapai nilai 50 - 69, dan Sembilan belas siswa (54\%) mencapai nilai $<50$. Sedangkan Kriteria Ketuntasan Minimal (KKM) yang ditetapkan adalah 70. Dengan demikian 
ketuntasan klasikal baru mencapai 6,67 \%. Lebih jelas dapat dilihat pada tabel berikut:

Tabel 1. Hasil Pre-test Uji Kompetensi Menulis Teks Prosedur

\begin{tabular}{|c|c|c|c|}
\hline No & $\begin{array}{c}\text { Rentang } \\
\text { Nilai }\end{array}$ & $\begin{array}{c}\text { Jumlah } \\
\text { Siswa }\end{array}$ & Persentase \\
\hline 1 & $70-100$ & 2 & 5,71 \\
\hline 2 & $50-69$ & 20 & 57,14 \\
\hline 3 & $0-49$ & 13 & 37,14 \\
\hline & Rerata & 52,0 & \\
\hline
\end{tabular}

Dalam kegiatan inti pembelajaran, siswa biasanya diberi contoh teks monolog berbentuk prosedur dan siswa diminta untuk mencari arti dari teks tersebut yang kemudian dirangkai menjadi sebuah kalimat yang benar. Proses pembelajaran seperti itu sudah biasa dilakukan oleh penulis dan ternyata hasil pembelajaran siswa tidak sesuai yang diharapkan dan siswa masih dibawah Kriteria Ketuntasan Minimal (KKM). Penulis memperoleh data keaktifan siswa dari hasil pengamatan melalui refleksi yang dilakukan bahwa siswa terlihat pasif, bosan dan bahkan ada beberapa siswa yang mengeluh tidak percaya diri dalam mengungkapkan ide atau gagasannya. Mereka tentunya kesulitan dalam mengerjakan tugas yang diberikan oleh guru. Hal ini sangat mengundang pertanyaan dan asumsi bahwasannya metode pembelajaran tersebut tidak berhasil (gagal) dan cenderung tidak efektif.

Setelah mengamati uraian di atas, dapat dilihat sebuah gambaran kegagalan terhadap hasil dan proses belajar dan hal tersebut merupakan masalah yang harus segera diatasi. Sebagai upaya memperbaiki kegagalan tersebut penulis berusaha mencari metode dan strategi pembelajaran yang tepat sebagai solusi selanjutnya. Penulis sadar bahwa di era Kurikulum 2013 (KURTILAS) ini, guru dituntut untuk kreatif dan inovatif. Guru harus mampu mencari satu teknik pembelajaran yang sesuai dengan situasi dan kondisi kelas. Prinsip PAIKEM (Pembelajaran Aktif, Inovatif, Kreatif, Efektif dan Menyenangkan) harus dilaksanakan. Guru bukan lagi merupakan sosok yang ditakuti dan bukan pula sosok otoriter, tetapi guru harus jadi seorang fasilitator dan motor yang mampu memfasilitasi dan menggerakkan siswanya untuk mendapatkan ilmu pengetahuan yang mereka butuhkan.

Berdasarkan paparan permasalahan di atas, penulis tertarik untuk mengkaji tentang "Peningkatan Keaktifan Dan Hasil Belajar Bahasa Inggris Kompetensi Menulis Teks Prosedur Melalui Model Pembelajaran Make A Match Siswa Kelas IX MTs Negeri 5 Kuningan Tahun Pelajaran 2019/2020".

\section{METODE}

Penelitian Tindakan Kelas ini dilaksanakan di MTs Negeri 5 Kuningan. Alamat sekolah di Jalan Tsanawiyah No. 25 Kecamatan Darma Kabupaten Kuningan. Penelitian ini dimulai Bulan September 2019 sampai bulan Nopember 2019 (semester 1). Penelitian ini dilaksanakan dalam 2 siklus, masing-masing siklus dijabarkan dalam 4 tahapan, yaitu tahap perencanaan, tindakan, pengamatan dan refleksi. Peneliti sebagai Guru Model berkolaborasi dengan Guru Bahasa Inggris yang mengajar di sekolah yang sama. Subyek penelitian yang di ambil adalah kelas IX MTs Negeri 5 Kuningan. Kelas IX 9 berjumlah 35 siswa, laki-laki 14 dan perempuan 21 siswa dengan latar belakang sosial-ekonomi siswa mayoritas anak buruh dan petani dengan tingkat kesejahteraan menengah ke bawah. Bukubuku pembelajaran yang dimiliki sendiri masih terbatas.

Teknik pengumpulan data yang digunakan dalam penelitian tindakan kelas ini adalah menggunakan teknik: 1) 
observasi dilakukan oleh peneliti dan kolaborator pada dokumen-dokumen atau arsip yang berupa hasil belajar siswa dan observasi langsung pada saat proses belajar mengajar Bahasa Inggris di dalam kelas, 2) tes dilakukan untuk mengetahui hasil belajar siswa dalam menulis teks prosedur, juga untuk membandingkan hasil belajar siswa yang diperoleh dari pra siklus, siklus 1 , dan siklus 2

Teknik analisis data yang digunakan untuk variabel pertama yaitu keaktifan siswa adalah teknik deskriptif kualitatif yang menganalisis sikap dan perilaku siswa dalam proses pembelajaran kompetensi menulis teks prosedur. Sedangkan untuk variable kedua yaitu hasil belajar teknik yang digunakan adalah berupa teknik deskriptif kuantitaif yaitu menganalisis data tes yang berupa ratarata nilai sebelum siswa diberi tindakan, rata-rata nilai pada siklus 1 , dan rata-rata nilai pada siklus 2 .

\section{HASIL DAN PEMBAHASAN Siklus 1}

Perencanaan siklus 1 meliputi kegiatan antara lain: Pembuatan RPP, pembuatan materi pembelajaran, pengadaan media pembelajaran, pembuatan lembar pengamatan terstruktur, konfirmasi kesediaan pengamat, serta menyiapkan kamera untuk mendokumentasikan kegiatan pembelajaran.

Pelaksanaan penelitian tindakan kelas siklus 1 dilaksanakan selama 3 kali pertemuan. Pertemuan dilaksanakan pada tanggal 21, 23 dan 28 Oktober 2019. Pada pertemuan 1 yaitu Hari Rabu tanggal 21 Oktober 2019 (2 x 40 menit) guru mengawali pembelajaran dengan menyampaikan tujuan pembelajaran. Setelah menyampaikan tujuan pembelajaran guru memberikan apersepsi dan menjelaskan tentang kata kerja dan kalimat perintah (imperative) yang akan digunakan dalam teks prosedur. Guru meminta siswa menyusun tempat duduk sedemikian rupa satu baris 7 kursi. Kemudian membagikan kartu dari kertas buffalo yang berisikan kata - kata untuk membentuk kalimat perintah. Dilanjutkan dengan pembahasan hasil kerja siswa dan diakhiri dengan kesimpulan pelajaran hari itu.

Pada pertemuan ke 2 ( 2 x 40 menit) yang dilaksanakan pada Hari Jumat 28 Oktober 2019, guru mengawali pembelajaran dengan menyampaikan tujuan pembelajaran. Setelah penyampaian tujuan pembelajaran, guru memberikan apersepsi dan pemberian contoh teks prosedur. Siswa mengamati contoh teks tersebut. Lalu guru menyampaikan struktur generic dari teks prosedur. Setelah siswa betul-betul memahami struktur generic teks prosedur, pembelajaran dilakukan diluar kelas. Guru memilih beberapa siswa yang memiliki kemampuan lebih untuk menjadi ketua kelompok. Siswa tersebut diberikan kartu yang berisi kalimat pertama dari teks prosedur. Siswa lain secara acak akan diberi kartu yang berisi kalimat berikutnya. Masing-masing teks berisi 7 kalimat. Mereka harus mencari ketua kelompok yang mempunyai kalimat berhubungan dengan kartu mereka. Setelah berkumpul mereka harus menyusunnya menjadi paragraph teks prosedur yang benar. Dalam satu kelas ada 35 siswa, sehingga akan terbentuk 5 teks prosedur yang berbeda. Setelah semua kelompok berhasil menyusun kalimat menjadi paragraph, kartu ditarik kembali dan ditukar dengan ketua kelompok lainnya. Demikian seterusnya. Pada pertemuan ke-3 (2 x 40 menit) yang dilaksanakan pada Hari Rabu tanggal 29 Oktober 2019, guru bersama siswa membuat kesimpulan tentang materi menulis teks prosedur. Kemudian dilakukan evaluasi. Dari evaluasi siklus 1 menunjukan adanya peningkatan kompetensi siswa dalam menulis teks 
prosedur. Sebanyak 2 siswa (6,67\%) sudah mencapai ketuntasan atau mencapai nilai 70 atau lebih, dengan rerata 52 .

Tabel 1. Hasil Ulangan Bahasa Inggris Untuk Kompetensi Menulis Teks Prosedur Siklus 1

\begin{tabular}{|c|c|c|c|}
\hline No & $\begin{array}{c}\text { Rentang } \\
\text { Nilai }\end{array}$ & $\begin{array}{c}\text { Jumlah } \\
\text { Siswa }\end{array}$ & Persentase \\
\hline 1 & $70-100$ & 29 & 82,85 \\
\hline 2 & $50-69$ & 5 & 14,28 \\
\hline 3 & $0-49$ & 1 & 2,85 \\
\hline & Rerata & 85,43 & \\
\hline
\end{tabular}

Hasil pengamatan pada siklus 1 yang dilakukan menggunakan lembar observasi berbentuk tabel keaktifan. Indikatornya keaktifan yang diamati yaitu: mental activities (memperhatikan penjelasan guru), writing activities (menulis), oral activities (bertanya, menjawab, melakukan diskusi kelompok).

Berdasarkan data yang diperoleh dari pengamatan terhadap proses pembelajaran pada siklus 1 dapat dilihat bahwa $71,42 \%$ dari siswa sudah aktif dalam kegiatan pembelajaran.

Pengamatan terhadap guru menunjukan bahwa penyampaian materi masih kurang bervariasi, contoh-contoh teks belum diberikan secara intens. Disamping itu perlu ditekankan juga pada penggunaan media pembelajaran yang menggunakan TIK.

Mengacu pada data hasil evaluasi pembelajaran dan hasil pengamatan maka peneliti melakukan refleksi dan hasilnya adalah: (1) guru perlu memberikan penjelasan yang lebih bervariasi dan memberikan contoh teks yang banyak, (2) guru perlu menekankan pada penggunaan media TIK untuk pembelajaran.

\section{Siklus 2}

Perencanaan siklus 2 menekankan pada perbaikan yang ada pada siklus sebelumnya yaitu dengan memperbanyak penjelasan dan contoh teks prosedur serta penggunaan power point dalam penyampaiannya kepada siswa.

Pertemuan pertama, penulis menyampaikan materi yang sama dengan siklus 1 namun ada perbedaan penggunaan power point. Kegiatan pembelajarannya juga sama menggunakan kartu make a match. Pertemuan kedua guru menyampaikan materi teks prosedur dengan struktur generiknya. Namun terdapat manipulasi teks prosedur dalam kartu make a match. Dalam teks prosedur ini ditambahkan temporal conjunction yang sangat membantu siswa dalam menyusun teks prosedur. Pertemuan ketiga, guru bersama siswa membuat kesimpulan dari materi menulis teks prosedur. Kemudian evaluasi siklus 2 .

Hasilnya menunjukan adanya peningkatan yang signifikan. Ini terbukti dari hasil evaluasi yang menunjukan 29 siswa $(82,85 \%)$ telah mencapai KKM yaitu memperoleh nilai 70 atau lebih. Hanya 5 yang masih memperoleh nilai 50-69 dan 1 orang siswa yang memperoleh nilai dibawah 50. Nilai rerata 85,43 . Selengkapnya dapat dilihat pada tabel berikut:

Tabel 2. Hasil Ulangan Bahasa Inggris Untuk Kompetensi Menulis Teks Prosedur Siklus 2

\begin{tabular}{|c|c|c|c|}
\hline No & $\begin{array}{c}\text { Rentang } \\
\text { Nilai }\end{array}$ & $\begin{array}{c}\text { Jumlah } \\
\text { Siswa }\end{array}$ & Persentase \\
\hline 1 & $70-100$ & 29 & 82,85 \\
\hline 2 & $50-69$ & 5 & 14,28 \\
\hline 3 & $0-49$ & 1 & 2,85 \\
\hline & Rerata & 85,43 & \\
\hline
\end{tabular}

Sedangkan dari aspek keaktifan siswa, hasil pengamatan menunjukan seluruh siswa sudah terlihat aktif dalam kegiatan. Terlihat dari tingkat keaktifan mencapai $91,42 \%$ dari siswa sudah aktif dalam pembelajaran.

Pengamatan terhadap kinerja guru sudah cukup baik dengan indikator yang telah ditetapkan antara lain: (1) membuka pelajaran dangan apersepsi, 
memotivasi siswa, dan menyampaikan tujuan pembelajaran,(2) menjelaskan dengan baik petunjuk kerja dan materi pembelajaran, (3) membuka kesempatan bertanya, (4) memberikan pertanyaan dan penguatan, (5) membimbing siswa dalam kerja kelompok, menggunakan waktu secara efektif, (7) menutup pelajaran dengan simpulan dan nasehat, (8) mengembangkan nilai-nilai karakter sesuai RPP. Atas pencapaian (achievement) tersebut peneliti merasa sudah cukup berhasil dalam kegiatan perbaikan pembelajaran ini.

\section{Keaktifan Siswa}

Berdasarkan data-data yang diperoleh dari proses kegiatan belajar mengajar mulai pra siklus, siklus 1 dan siklus 2, kita dapat melihat keaktifan peserta didik mengalami peningkatan yang signifikan. Peningkatan tersebut dapat dilihat pada tabel berikut ini.

Tabel 3. Keaktifan Peserta Didik pada Proses Kegiatan Belajar Mengajar

\begin{tabular}{|l|l|l|l|l||}
\hline No & Aktifitas Siswa & $\begin{array}{l}\text { Pra } \\
\text { Siklus }\end{array}$ & $\begin{array}{l}\text { Siklus } \\
1\end{array}$ & $\begin{array}{l}\text { Siklus } \\
2\end{array}$ \\
\hline 1 & $\begin{array}{l}\text { Mental } \\
\text { Activities } \\
\text { (Memperhatikan } \\
\text { Penjelasan } \\
\text { Guru) }\end{array}$ & $\begin{array}{l}15 \text { Siswa } \\
(43 \%)\end{array}$ & $\begin{array}{l}25 \\
\text { Siswa } \\
(71 \%)\end{array}$ & $\begin{array}{l}34 \\
\text { Siswa } \\
(97 \%)\end{array}$ \\
\hline 2 & $\begin{array}{l}\text { Writing } \\
\text { Activities } \\
\text { (Mencatat) }\end{array}$ & $\begin{array}{l}17 \text { Siswa } \\
(49 \%)\end{array}$ & $\begin{array}{l}30 \\
\text { Siswa } \\
(86 \%)\end{array}$ & $\begin{array}{l}34 \\
\text { Siswa } \\
(94 \%)\end{array}$ \\
\hline 3 & $\begin{array}{l}\text { Oral Activities } \\
\text { (Bertanya) }\end{array}$ & $\begin{array}{l}15 \text { Siswa } \\
(43 \%)\end{array}$ & $\begin{array}{l}20 \\
\text { Siswa } \\
(57 \%)\end{array}$ & $\begin{array}{l}26 \\
\text { Siswa } \\
(74 \%)\end{array}$ \\
\hline 4 & $\begin{array}{l}\text { Oral Activities } \\
\text { (Menjawab) }\end{array}$ & $\begin{array}{l}13 \text { Siswa } \\
(37 \%)\end{array}$ & $\begin{array}{l}25 \\
\text { Siswa } \\
(71 \%)\end{array}$ & $\begin{array}{l}32 \\
\text { Siswa } \\
(91 \%)\end{array}$ \\
\hline 5 & $\begin{array}{l}\text { Oral Activities } \\
\text { (Diskusi) }\end{array}$ & $\begin{array}{l}15 \text { Siswa } \\
(43 \%)\end{array}$ & $\begin{array}{l}25 \\
\text { Siswa } \\
(71 \%)\end{array}$ & $\begin{array}{l}35 \\
\text { Siswa } \\
(100 \%)\end{array}$ \\
\hline \multicolumn{2}{|l|}{ Rata-Rata } & 15 Siswa & $\begin{array}{l}25 \\
\text { Siswa }\end{array}$ & $\begin{array}{l}32 \\
\text { Siswa }\end{array}$ \\
\hline \multicolumn{2}{|l|}{ Persentase } & $42.85 \%$ & $71.42 \%$ & $91.42 \%$ \\
\hline
\end{tabular}

\section{Hasil Belajar Siswa}

Berdasarkan data-data yang diperoleh dari hasil ulangan menulis, dapat dilihat bahwa pada pra siklus nilai rata-rata tes menulis peserta didik baru mencapai 48, dan pada siklus 1 setelah diberi tindakan nilai rata-rata menjadi 52 . Siswa yang tuntas KKM baru 2 siswa. Namun peneliti dan kolaborator merasa hal itu masih jauh dari yang diharapkan sehingga dilakukan diskusi dan dilakukan perbaikan proses pembelajaran pada siklus 2

Setelah melaksanakan tindakan di siklus 2, nilai ulangan menulis siswa meningkat menjadi 85. Sebanyak 29 siswa tuntas KKM. Dengan demikian hasil pelaksanaan tindakan siklus 2 telah mengalami peningkatan yang signifikan.

Peningkatan hasil belajar dalam menulis teks prosedur melalui model pembelajaran Make a Match pada siswa kelas IX MTs Negeri 5 Kuningan Tahun Pelajaran 2019/2020 Semester 1.

Sebelum kegiatan PTK, peneliti mengajarkan materi menulis teks prosedur melalui metode terjemah. Proses pembelajaran dimulai dengan guru memberikan apersepsi dan motivasi secara umum. Guru menyampaikan materi kalimat perintah, siswa diminta untuk menyusun kata-kata acak menjadi kalimat perintah. Kemudian pertemuan berikutnya guru menyampaikan materi teks prosedur menggunakan materi yang ada dalam LKS. Siswa menerjemahkan kalimatkalimat acak yang disediakan kemudian setelah dibahas artinya baru disusun kalimat-kalimat acak tersebut menjadi teks prosedur. Dengan metode tersebut, penulis mengamati bahwa hasil belajar siswa tidak memuaskan, banyak siswa yang tidak tuntas KKM. Dan siswa yang kurang pandai terlihat malas Karena harus membuka dan memilah kosakata dalam kamus. Sehingga kelas menjadi pasif.

Pada siklus 1, proses pembelajaran dimulai dengan guru menyampaikan apersepsi dan motivasi khusus pada materi yang akan disampaikan. Guru menyampaikan materi kalimat perintah. Siswa diminta untuk menyusun kata-kata 
acak yang dituliskan pada kertas-kertas kecil yang dibagikan pada siswa secara acak. Siswa mencari pasangan berjumlah 7 orang untuk menyusun menjadi sebuah kalimat perintah. Pertemuan kedua, guru menyampaikan materi teks prosedur. Siswa diminta untuk menyusun kalimatkalimat acak menjadi teks prosedur. Kalimat-kalimat tersebut dicetak pada potongan kertas-kertas kecil lalu dibagikan kepada siswa secara acak. Siswa mencari pasangan sebanyak 7 siswa untuk menyusun menjadi teks prosedur. Setelah dilakukan ulangan harian ternyata hasilnya belum memuaskan. Dari hasil pengamatan, guru menyampaikan materi secara manual, ditulis dipapan tulis sehingga kurang menarik bagi siswa. Proses mencari pasangan dilakukan didalam kelas sehingga mobilitasnya terganggu meja dan kursi.

Pada Siklus 2, proses pembelajaran dimulai dengan guru menyampaikan apersepsi, motivasi pembelajaran lebih dititik beratkan lagi pada materi yang akan disampaikan. Serta disampaikan juga silabus, SK, KD dan indicator keberhasilan pembelajaran materi menulis teks prosedur. Guru menyampaikan materi kalimat perintah dan teks prosedur menggunakan bantuan alat pembelajaran LCD. Dari perbedaan ini siswa terlihat lebih antusias. Kemudian siswa diberikan kata-kata acak dan disusun menjadi kalimat perintah. Setelah selesai, mereka diberikan kalimat-kalimat acak yang dicetak dalam potongan-potongan kertas dan mencari pasangan sebanyak 7 siswa untuk disusun menjadi teks prosedur. Semua kegiatan mencari pasangan pada siklus 2 dilakukan diluar kelas, sehingga mobilitas siswa lebih mudah berbeda dengan siklus 1. Berdasarkan pengamatan, siswa lebih aktif Karena tidak terhalang meja dan kursi. Setelah dilakukan ulangan menulis hasilnya meningkat signifikan.

\section{KESIMPULAN}

Berdasarkan hasil penelitian dan pembahasan, berikut ini disampaikan kesimpulan terkait dengan penelitian ini:

Penggunaan model pembelajaran make a match dapat meningkatkan keaktifan belajar siswa kelas IX MTs Negeri 5 Kuningan, semester 1 tahun pelajaran 2019/2020, hal tersebut dapat dibuktikan dengan persentase keaktifan siswa pada siklus $170 \%$ siswa aktif. Kemudian pada siklus 2 meningkat menjadi $92 \%$.

Dengan menggunakan model pembelajaran make a match prestasi siswa kelas IX MTs Negeri 5 Kuningan, semester 1 tahun pelajaran 2019/2020 dalam kompetensi menulis teks prosedur meningkat secara signifikan.

Hal tersebut dibuktikan dengan nilai ratarata siklus 1 hanya 52,00 dan yang lulus KKM hanya 2 anak $(5,71 \%)$. Sedangkan pada siklus 2 nilai rata-rata meningkat menjadi 85,43 dan siswa yang lulus KKM sebanyak 29 anak (82, 85\%).

Bagi Guru Mata Pelajaran: sebaiknya hasil penelitian ini ditindaklanjuti dan dilaksanakan oleh seluruh guru mata pelajaran, sehingga diharapkan mutu pendidikan dapat lebih ditingkatkan.

Materi teks prosedur yang digunakan dalam model pembelajaran make a match sebaiknya lebih banyak sehingga pengalaman anak dalam menulis teks prosedur lebih banyak.

Pembelajaran menulis teks prosedur dengan model pembelajaran make a match dapat dikembangkan dengan model-model pembelajaran yang lain yang mampu meningkatkan kreativitas dan aktivitas siswa.

\section{DAFTAR PUSTAKA}

Agustien, Helena I.R. 2004. Bahan Pelatihan Terintegrasi Kurikulum 
2004 Berbasis Kompetensi Bahasa Inggris SMP. Semarang: LPMP Jawa Tengah.

Aqib, Zainal, 2013. Model-Model, Media, dan Strategi Pembelajaran Kontekstual (Inovatif). Bandung: Yrama Widya.

Bima M, Bahtiar Dkk. 2005. Let's Talk. Bandung. Pakar Raya.

Hananto, Senno. Pengertian Hasil Belajar Menurut Para Ahli. Diunduh pada tanggal 14 Oktober 2015 dari http://www.scribd.com/

Hartono, Yuni. 2011. Student Performance Enhancing Efforts to Revealing Monologue in the Prosedur Text Through the Demonstration Method in the Ninth Grade Students of SMP Negeri 1 Sumobito Jombang. Diunduh tanggal 14 Oktober 2015 dari http://www.scrib.com.

Hermawan. 2007. Pengertian Keaktifan Belajar Peserta Didik. Diunduh tanggal 12 Oktober 2015 dari http://www.buatskripsi.com.

Nasokha. 2011. "Peningkatan Keterampilan Menulis Teks Recount Melalui Pembiasaan Menulis Diary Pada Kelas 8A SMP Negeri 2 Pekalongan Tahun Pelajaran 2010/2011". Jurnal Pendidikan Pedagogik. Vol. 5, No. 2, Mei 2011, hal. 33.

Sardiman. 2001. Aktivitas Belajar. Diunduh tanggal 13 Oktober 2015 dari http://www.buatskripsi.com.

Slamento. 1995. Pengertian Belajar. Diunduh pada tanggal 13 Oktober 2015 dari https://techonly13.wordpress.com/2 010/07/03/belajar-dan-hasil-belajar/.

Sudjana, Nana. 1988. Pengertian Belajar. Diunduh pada tanggal 13 Oktober 2015 https://techonly13.wordpress.com/2 010/07/03/belajar-dan-hasil-belajar/

Febriana, A. (2011). Penerapan Model Pembelajaran Kooperatif Tipe Make A Match Untuk Meningkatkan Kualitas Pembelajaran Ips Siswa Kelas V Sdn Kalibanteng Kidul 01 Kota Semarang (Application of Cooperative Learning Model Type Make A Match to Enhance Quality of Learning Social. Jurnal Kreatif: Jurnal Kependidikan Dasar, 1(2).

Masa, N., Murda, I. N., \& Mahadewi, L. P. P. (2017). PENGARUH MODEL PEMBELAJARAN MAKE A MATCH TERHADAP HASIL BELAJAR IPS SISWA KELAS V SD. MIMBAR PGSD Undiksha, $5(2)$.

Harefa, D. (2020). Peningkatan Hasil Belajar Siswa Dengan Pembelajaran Kooperatif Make A Match Pada Aplikasi Jarak Dan Perpindahan. Geography: Jurnal Kajian, Penelitian dan Pengembangan Pendidikan, 8(1), 01-18.

NAFIS, N. J. (2015). Penerapan Model Pembelajaran Kooperatif Tipe Make a Match Untuk Meningkatkan Prestasi Belajar Bahasa Inggris Siswa Kelas III MI Senden Kampak Trenggalek.

Suprapta, D. N. (2020). Penggunaan Model Pembelajaran Make a Match Sebagai Upaya Meningkatkan Hasil Belajar Bahasa Inggris Siswa. Journal of Education Action Research, 4(3).

Hikmawati, R. (2015). PENINGKATAN KEMAMPUAN SISWAMENULIS TEKS PROSEDUR MELALUI MODEL PEMBELAJARAN MAKE A MATCH. Jurnal Penelitian Tindakan Kelas, 16(2) 